\title{
Structure and Nature of Competition in the Market for Financial Audit Services in Mexico
}

\author{
Juan A. Toscano M. ${ }^{1} \&$ María A. García-Benau ${ }^{2}$ \\ ${ }^{1}$ Institute of Social Sciences and Management, Autonomous University of Juarez City, Mexico \\ ${ }^{2}$ School of Economics, University of Valencia, Spain \\ Correspondence: Juan A. Toscano M., Ph. D., Institute of Social Sciences and Management, Autonomous University \\ of Juarez City, Mexico. Tel: 52-65-6688-3826, E-mail: jtoscano@uacj.mx
}

Received: May 1, 2014

Accepted: May 19, 2014

Online Published: May 21, 2014

doi:10.5430/jbar.v3n2p1

URL: http://dx.doi.org/10.5430/jbar.v3n2p1

\begin{abstract}
The structural paradigm emphasizes that the nature of competition in a market, is closely related to the structure of the market and in particular its level of concentration. The objective of this research work is to present empirical evidence on the structure and nature of competition in the market for financial audit services in Mexico during the period from 2000 to year 2007. To do this, we have calculated several measures of concentration, using a sample of 1,344 financial audit reports of companies that are registered as issuers of shares in the capital market of the Stock Exchange in Mexico. The results show that the market for financial audit market in Mexico is highly concentrated and under the control of a few audit firms, specifically of Large International Firms, better known in the field business around the world as the "Big 4". Also the results show that the nature of the competition in the market for financial audit services in Mexico is that, in imperfect markets, known as an oligopoly.
\end{abstract}

Keywords: Structure, Nature of competition, Market for financial audit service, Mexico, Oligopoly

\section{Introduction}

The study of the financial audit market structure, its competitive nature and its high level of concentration have been analyzed by a significant number of empirical studies collected by the accounting research literature (Zeff and Fossum, 1967; Rhode, Whitsell and Kelsey, 1974; Danos and Eichenseher, 1986; Moizer and Turley, 1987; 1989; Beattie and Fearnley, 1994; Wolk, Michelson and Wootton, 2001; Thavapalan, Moroney, and Simnett, 2002; Beattie, Goodacre and Fearnley, 2003; Carrera, Gutierrez and Carmona, 2005; Feldman, 2006; McMeeking, Peasnell and Pope, 2007; McMeeking, 2007; García Benau and Novejarque, 2009; Caban-García and Cammack (2009); Kallapur, Sankaraguruswamy and Zang, 2010; Dunn, Kohlbeck and Mayhew, 2011). The high level of concentration in the market for financial audit services has caused a negative impact, on the world professional practices, which are currently evident and affect the very essence of the professional practice of financial audit services. According to Carrera et al., (2005), said that after the Enron financial scandal discovered during the year of 2002, the market for financial audit services in the world has come to convulse again, due to the effects that mergers occurring between large international audit firms have generated in that market. This event will produce a higher concentration than existed in the world financial audit market and also generate more competition with the rest of the other auditing firms participating in that market. Also, the international regulatory institutions internationally have continued to express concern regarding the high power achieved by the Big 4, especially for the negative consequences that may be occurring for the proper functioning of audit market because the supply of financial audit services in the world is dominated by a few firms (Sarbanes-Oxley Act of 2002, American Assembly Report, 2005; Oxera Report, 2006; GAO 2003; European Commission, 2010; Competition Commission, 2013).

The research work presented in this article, has the main objective to provide empirical evidence about the structure and the nature of competition in the market for audit services in Mexico. To do this, the sample we used was based on data contained in the web page of the Mexican Stock Exchange (MSE) during the period from 2000 to 2007. This research work is based on the analysis of a sample integrated by 1,344 financial audit reports of companies that are registered with the MSE which in turn were audited by various external audit firms. After this introduction, we make an analysis on the structuralist paradigm. Then, we present an analysis of the literature review on the study of the market financial audit services. Next, we show the research methodology that we have applied to the empirical study. 
Then, we make an empirical analysis on the structure and the nature of competition in the financial audit market of Mexico. Finally we present the conclusions of this research work.

\section{Structuralist Paradigm adapted to the Financial Audit Market}

The analysis of the financial audit market is based on doctrinal principles established by the industrial economy to analyze the behavior of markets, known as the structuralist paradigm. The argument of this is that the structure of a particular market will determine to a large extent, the behavior of firms competing in it and therefore the efficiency in resource allocation. This type of analysis is based, therefore, on the analysis of the relationships between structure, behavior and results. It is considered that the results of the market "efficient or inefficient" will depend on the type of competition in the same "perfect, imperfect, oligopoly, monopoly, etc.", these aspects are closely related to variables related to market structure, among which acquires special importance level of concentration (Bueno and Morcillo, 1993).

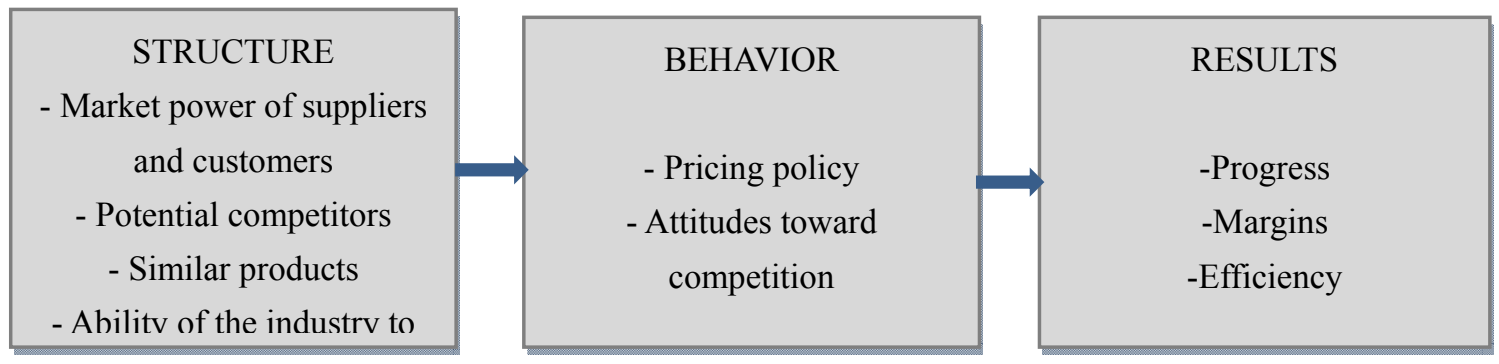

Graphic 1. The Structuralist paradigm

According to the reasoning behind the structuralist paradigm and observed in Graphic 1, we assume that the success of a company is determined by the characteristics of the industry, and by the behavior of the companies operating in it. The structure, defined as the intensity of competition in the industry, it is thus very important in the face of an adequate interpretation of the existing concentration. As noted by Porter (1985), the intensity of competition is explained by five factors: the power of suppliers, power of customers, potential competitors, similar products and the industry's ability to lead the competition. These factors define the behavior of the companies involved in the industry, through its pricing policy and attitude toward competition. All this lead to what falls squarely on the outcome, by which we analyze the efficiency of the market. If we adapt the doctrinal concept of structuralist paradigm to study the market for financial audit services in Mexico, we can assume that if we analyze its structure and in particular its level of concentration, not only we will be able to meet its operating structure and type of competition, but also get to explain the reasons for the behaviors of both financial audit firms and audited companies.

\section{Literature Review}

Four decades ago, the international journal The Accounting Review in the United States of America published an article entitled "An Analysis of Large Audit Clients" Authors Zeff and Fossum (1967), which brought empirical evidence on the high level of concern concentration of the audit market. Thereafter, the accounting researchers have been analyzing the market for audit services in the U.S.A.

Rhode et al., (1974) found in his research an increasing dominance of the Big Eight compared with Zeff and Fossum study. Eichenseher and Danos (1981) in their research found lower supplier concentration compared to previous studies and also found higher concentration in regulation industries due to economies of scale. Danos and Eichenseher (1986) have demonstrated that the supplier concentration in non-regulated industries decreases over time due to lower economies of scale. Tomczyk and Read (1989) found in their research that the concentration of suppliers among the Big Four remains relatively stable at CR4=0.5. Minyard and Tabor (1991) have demonstrated that the mergers of Big Eight form Big Six do not have a significant influence on the concentrarion. Wolk et al., (2001) in their research found an increasing concentration rates over time due to mergers among Big Eight and Big Six. Caban-García and Cammack (2009) have demonstrated an increase of concentration in the year after the merger of PriceWaterhouse and C\&L and takeover of Arthur Andersen by Ernst \& Young, and also have demonstrated a decreasing concentration rates two years after the merger. Kallapur, Sankaraguruswamy and Zang (2010) and Dunn et al., (2011) in their research found an increasing concentration of Big 4 over time, and also found an increasing equivalence of market shares among Big 4. 
Although a little later than in the United States, the accounting research literature has also been collecting a series of papers on the study of the audit market in the rest of the world. Maijoor et al., (1995) studied the concentration of the audit market in the Netherlands. For this purpose the authors used the indices C4 and Herfindahl index, both calculated on the basis of measurement (indirect surrogate), consisting of the number of auditors employed by an audit firm, considered as a measure of firm size, or participation market it. This approach assumes a connection between the scope of audit firm, expressed by the number of auditors employed, and the associated market share. However, this method does not take into account the fact that new orders can be committed by an increase in productivity without employing more auditors.

Schaen and Maijoor (1997) examine the structure of the audit market in Belgium and identify the factors that affect the level of auditor concentration. They used a sample of 10,500 clients of audit firms ranked 62 different industry groups. The results show that the dominant structure of the audit market in Belgium maintains a loose oligopoly. Garcia-Benau et al., (1998), are the pioneers in analyzing the structure of the audit market in Spain. They used a sample of medium and large firms during the period 1992-1994, which we calculated the concentration indices of order $n$ and the Herfindahl index, noting that in that market concentration is due to the preference of companies to large international firms. This research unlike other studies, covering both listed companies and unlisted companies, so that the spectrum covered by the sample of firms is much broader as it encompasses different market segments Spanish. The results conclude that the Spanish audit market is an imperfect competition and of oligopoly type.

Thavapalan et al., (2002) examined the effects of PricewaterhouseCoopers merger on market concentration in Australia. In their study, they used a database consisting of 1194 companies in 1997 and 1,236 in July 1997 registered on the Australia Stock Exchange (ASX) classified in 24 industries. Their results indicate that reaches PricewaterhouseCoopers leadership with a $19.5 \%$ market share calculated based on the surrogate of the number of audits, on the other hand, based on the fees billed reaches the second place in the ranking of the Big Five with $22.3 \%$ of market share achieved. Beattie et al., (2003) to carry out their study simulated the effects of the merger between large international firms (Arthur Andersen and Deloitte \& Touche) analyzed a sample of the 2,189 companies listed on the London Stock Exchange. The results highlight that following the merger of the two firms reached a projected market share of $96 \%$ for the four major international firms (Big 4), noting also that the international firm (PriceWaterhouseCoopers) absorbed a market share greater than $70 \%$ in six of the thirty-eight sectors analyzed and a $50 \%$ share in seven.

Grothe (2005) in his research for Germany found an oligopolistic market structure with high degree of concentration. Baskerville and Hay (2006) for their study on the effects of mergers in the audit market in New Zealand. It uses a database related to the frequency of the audit, the numbers of members in each of the major auditing firms and the opinions revealed in interviews with partners. The results indicate that after the merger there are reductions in the costs of audits, or collusion among audit firms to raise prices. McMeeking et al., (2007) examined the effects of mergers between large international firms and the effects after the resignation of the international firm Arthur Andersen on the concentration, and price competitiveness of the audit market in the UK. The results of the study indicate that large international audit firms increased their market shares between 1985 and 2002 because of mergers and expansion into new sectors. Bigus and Zimmermann, (2008) have demonstrated for the audit market of Germany a high concentration and Big 4 hold a market share of $90 \%$. Abidin et al., (2010) in their research found for the UK audit market an increase of concentration from CR4 $=0.67$ to 0.68 (Engagements) and from 0.88 to 0.96 (Fees) respectively. Breitkreuz and $\mathrm{Mu}$ ig, (2010) found for the Switzerland audit market that the concentration values remain relatively stable over time, and that the Market share of Big Three form 96\% (Fees) and 85\% (Engagements) respectively in 2008, and an insignificant market share of Deloitte. Quick and Sattler, (2011) examined the market of Germany and found an oligopoly position and dominance of Big 4 primarily in DAX.

\section{Methodology of Study}

The methodology of study for measuring the level of concentration in the audit market in Mexico, needs to determine a basic measure of market activity. For this, we need to select the surrogate of activity and we also need to ask a concentration measurement or analysis of how the total market activity is distributed among different firms auditors involved in it. The activity measurement audit market requires knowing the total supply existing therein. In this sense, the total audit services fees of each audit firm would be an appropriate measure of its absolute and relative position in the market. In this regard, the international literature highlights various jobs that audit fees charged by audit firms clients have been widely used to understand the structure of the audit market (Moizer and Turley, 1987; 1989; Tomczyk and Read, 1989; Iyer and Iyer, 1996, Pong, 1999; Quick and Wolz, 1999). 
However, in many countries, as it is for Mexico, there is no publicly available information on the audit services fees charged to clients. To overcome this limitation for the realization, the accounting researches had been using various indirect measures of activity in the audit market such as the turnover of the companies audited and its square root, the assets of the companies audited and its square root, the number of audits performed by each audit firm, the market value of the audited company and its quadratic transformation and the number of auditors from the audit firm (Dopuch and Simunic, 1980; Moizer and Turley, 1987; Tomczyk and Read, 1989; Beattie and Fearnley, 1994; Kwon, 1996; Wolk at al., 2001).

In this line, accounting researchers have demonstrated in their empirical work on the concentration in the audit market that the results are sensitive to the used "surrogate activity" indicator (Moizer and Turley, 1987; Tomczyk and Read, 1989; Pong, 1999; Quick and Wolz, 1999). Once we have selected the surrogate as a basis to measure the activity of the audit market, it is now necessary to define the measures of concentration through which we can understand how it is distributed the audit market between all active participants in it.

According to Carlton and Perloff (1999), the concentration is measured as a function of the market shares of some or all of the companies in the market. The simplest measure is called the concentration index of order $n$, which represents the market shares of the $n$ firms active in the market. The choice of the number of companies to analyze depends on the market that we are analyzing and calculating the target concentration. Analytically the concentration index of order $n$ takes the following form:

$$
\mathrm{IC} n=\sum_{1}^{n} \mathrm{~F} n / \mathrm{F}(1)
$$

where:

$$
\begin{aligned}
& \mathrm{IC} n=\text { market share of the } \mathrm{n} \text { largest firms } \\
& n=\text { number of companies analyzed }(1,2,4,6, \text { etc.) } \\
& \mathrm{F} n=n \text { surrogate firms (turnover } / \text { number of firms) } \\
& \mathrm{F}=\text { turnover } / \text { number of total market companies }
\end{aligned}
$$

Thus, an index of 0.50 IC4 financial audit market indicates that the four companies most active in the market, with the largest market, get half of the total sales revenue generated in that market. At the present time we believe that it will be very relevant for our empirical study to investigate the incidence rate IC1 and IC4, so that, on the one hand, we can specify the financial audit firm with the largest market share and, on the other, also know which are the four largest auditing firms in the Mexican audit market and that usually tend to coincide with major international firms best known as the "Big 4".

Another measure that has also been used to measure the concentration of the audit market is the Herfindahl index (IH). This index allows us to take into account the number of active audit firms as well as the dispersion in their activity levels. The Herfindahl index is defined as:

$$
\mathrm{IH}=\sum_{i=1}^{n}(\mathrm{Z} i)^{2}(2)
$$

where:

$$
\begin{aligned}
& \mathrm{IH}=\text { Herfindahl index } \\
& \mathrm{Zi}=\text { market share absorbed by the sample firms } \\
& \boldsymbol{n}=\text { number of firms active in the market }
\end{aligned}
$$

If the Herfindahl index is equal to one, it means or indicates that there is only one company active in the market, while if the Herfindahl index goes to zero, it means that we are in a market with many coexisting audit firms of similar size. Thus, a Herfindahl index of 0.25 indicates that the degree of market concentration is equivalent to the presence of four equal sized audit firms. As can be seen, the rate Henfindahl is sensitive to the number of companies active in the market and their level of activity, this means that small audit firms exert less influence on the index than larger audit firms, so the Herfindahl index can be understood as a measure of the dispersion of market shares, among the various companies operating within this market (Eichenseher and Danos, 1981, Johnson et al., 1995, Garcia-Benau et al., 1998). 


\section{Empirical Results}

To know the structure of the audit market in Mexico, and his competitive nature during the period from 2000 to 2007, we used a sample of 1,344 audit reports and their corresponding annual reports belonging to a total of 168 companies registered, on average, in the Mexican Stock Exchange and which in turn were audited by various external audit firms. Financial information that integrates the sample described above and presented below was obtained from the database published on the website (http://www.bmv.com.mx) of the Mexican Stock Exchange.

Table 1. Description of the sample

\begin{tabular}{lcccccccc}
\hline Concepts & $\mathbf{2 0 0 0}$ & $\mathbf{2 0 0 1}$ & $\mathbf{2 0 0 2}$ & $\mathbf{2 0 0 3}$ & $\mathbf{2 0 0 4}$ & $\mathbf{2 0 0 5}$ & $\mathbf{2 0 0 6}$ & $\mathbf{2 0 0 7}$ \\
\hline Number of companies audited & 141 & 148 & 155 & 161 & 171 & 185 & 191 & 192 \\
Number of Audit Firms & 20 & 21 & 20 & 22 & 22 & 23 & 23 & 23 \\
\hline
\end{tabular}

In the Table 1, we see that the total number of audit reports and related financial statements of different companies analyzed for each of the years from 2000 to 2007 were 141, 148, 155, 161, 171, 185, 191 and 192 respectively. On the other hand, we also see the total number of audit firms that participated in the tender for the provision of external audit services and therefore audited the companies analyzed in the same period mentioned above, were 20, 21, 20 , $22,22,23,23$ and 23 respectively.

It is necessary to clarify that in the absence of appropriate databases that allow us to analyze the total audited companies in Mexico, the sample used for our empirical investigation has been restricted to the segment of companies listed on the Mexican Stock Exchange. Also, given the sensitivity of the measures of concentration in relation to the samples used, we consider that the size of the companies included in the sample, particularly large companies, will bias concentration measurements upward so that the greater the size of the audited company, the greater the likelihood that the company is audited by a large audit firm (Dopuch and Simunic, 1980; Tonge and Wootton, 1991).

Given these limitations, we believe it is necessary to interpret the results of our empirical study with caution, since they probably reflect the bias of the sample used in this empirical study, which is composed mostly by large companies audited. Here is the empirical application of these two measures of concentration on the sample of our research, noting that for the calculation of both concentration indices we use as a surrogate the turnover of the company being audited (Moizer and Turley, 1987; Beattie and Fearnley, 1994; Wolk et al., 2001). In this section we present the results derived from the calculation of the concentration index of order $n$, using the turnover of the audit as a surrogate of it.

Table 2. Concentration in Mexican Audit Market by volume of the audited companies billing

\begin{tabular}{ccccccccc}
\hline Concentration Index & $\mathbf{2 0 0 0}$ & $\mathbf{2 0 0 1}$ & $\mathbf{2 0 0 2}$ & $\mathbf{2 0 0 3}$ & $\mathbf{2 0 0 4}$ & $\mathbf{2 0 0 5}$ & $\mathbf{2 0 0 6}$ & $\mathbf{2 0 0 7}$ \\
\hline C1 & $48 \%$ & $40 \%$ & $48 \%$ & $48 \%$ & $45 \%$ & $33 \%$ & $31 \%$ & $37 \%$ \\
C2 & $68 \%$ & $62 \%$ & $69 \%$ & $71 \%$ & $71 \%$ & $58 \%$ & $59 \%$ & $67 \%$ \\
C4 & $93 \%$ & $93 \%$ & $97 \%$ & $97 \%$ & $97 \%$ & $97 \%$ & $97 \%$ & $97 \%$ \\
C5 & $97 \%$ & $97 \%$ & - & - & - & - & - & - \\
\hline
\end{tabular}

It results in Table 2 we can see that there is a high level of concentration in the audit market in Mexico. Thus, we see that for the years 2000 and 2001 the Mexican audit market is dominated by five accounting firms (C5), and is referred to years from 2002 to 2007 that Mexican audit market is practically controlled and dominated by just four audit firms (C4). Likewise, we emphasize that for the years 2000 and 2001, the total activity level Mexican audit market is concentrated in 97\% represented by five auditing firms (C5), and that for the period for the years 2002 to 2007 the total activity level audit market average Mexican is concentrated in $97 \%$ represented by only four audit firms (C4). From the results obtained so far from the table 4, we can infer that the audit market Mexican is far from what scholars ideally industrial economy consider should be the structure of perfect competition, rather this situation seems to be a oligopolistic market behavior, as there are perceptible differences between the different audit firms 
forming the sample. So then we can see that there are a small number of audit firms, namely four, which have significant market power. Therefore, we can say that for the Mexican case there is unequal market structure, for the reason that not all active bidders audit service in the Mexican market are in the same situation with regard to market share they enjoy. This circumstance alienates the Mexican audit market from the perfect competition model, showing significant differences in the degree of competitiveness enjoyed by the different independent professional audit firms or auditors. It can be concluded that certain audit firms account for its position in the Mexican market, with a significant degree of influence, breaking, thus, one of the basic premises of the model of perfect competition. In this respect, the industrial organization literature considers an oligopoly to exist when the level of the market concentration is above 40\% (Scherer and Ross, 1990). The oligopolistic nature of Mexican audit market, can lead to the idea that this structure makes possible the existence of strong interdependence between the auditing firms that control the market, being able to explicit or implicit agreements to hinder that other auditing firms can grow enough to put its status in jeopardy. In an oligopoly in which there is a homogeneous product, as is apparently the audit market, the audit firms are aware of their interdependence because the market is concentrated in a few firms and so the actions of each of them will have a significant effect on its competitors immediate. This allows us to consider the possibility that the companies that control the market have incentives to reach collusive agreements, whose objective may be to place limits on the existence of competition, eliminating the competitive dynamics of the market. This approach has already been discussed in the literature on audit markets by Dopuch and Simunic (1980), who consider that the stability of the market shares of individual firms that are audit market leaders can be understood as a consequence of the existence of collusive agreements, ie agreements reached to eliminate competition.

To learn about the possible existence of such collusive agreements between auditing firms that dominate the audit Mexican market, it is necessary to perform a detailed analysis of the role played by each of the leading auditing firms in the audit Mexican market with special attention to the evolution of its activity in this market. Also, in order to know precisely which are these auditing firms, below is the description and occupied position in our sample, establishing for this purpose a ranking of such audit firms for the activity during the study period. This data is presented in Table 3.

Table 3. Participation of the Big 4 in Mexico by billing volume of audited companies

\begin{tabular}{lcccccccc}
\hline Audit Firm & $\mathbf{2 0 0 0}$ & $\mathbf{2 0 0 1}$ & $\mathbf{2 0 0 2}$ & $\mathbf{2 0 0 3}$ & $\mathbf{2 0 0 4}$ & $\mathbf{2 0 0 5}$ & $\mathbf{2 0 0 6}$ & $\mathbf{2 0 0 7}$ \\
\hline PWC & $20 \%(2)$ & $22 \%(2)$ & $47 \%(1)$ & $48 \%(1)$ & $45 \%(1)$ & $33 \%(1)$ & $31 \%(1)$ & $17 \%(3)$ \\
E\&Y & $48 \%(1)$ & $21 \%(3)$ & $22 \%(2)$ & $20 \%(3)$ & $20 \%(3)$ & $16 \%(4)$ & $17 \%(4)$ & $14 \%(4)$ \\
DTT & $7 \%(4)$ & $9 \%(4)$ & $21 \%(3)$ & $23 \%(2)$ & $26 \%(2)$ & $25 \%(2)$ & $27 \%(2)$ & $30 \%(2)$ \\
KPMG & $4 \%(5)$ & $5 \%(5)$ & $7 \%(4)$ & $6 \%(4)$ & $6 \%(4)$ & $23 \%(3)$ & $22 \%(3)$ & $36 \%(1)$ \\
AA & $18 \%(3)$ & $40 \%(1)$ & - & - & - & - & - & - \\
\hline
\end{tabular}

DTT $=$ Deloitte Touche Tohmatsu, EY $=$ Ernst $\&$ Young, PWC $=$ Price Waterhouse Coopers, KPMG $=$ KPMG. The number in parenthesis expresses the position of each company in an annual ranking of 1-4 years except for 2000 and 2001 where AA = Arthur Andersen firm, still part of large international firms.

As shown in Table 3, the audit firms that absorb more market share in our sample are indeed large international firms better known as the Big 5 up to 2002 and Big 4 up to 2007. Thus, the market situation in Mexico is not different from the one in audit markets in other countries, as we have seen in the section above concerning our review of the collected works of international literature, which evidences that the Mexican audit market is controlled, like in those other countries, by large international firms. We can also infer from the results in Table 3, that in the Mexican audit market there is an excessive competition between the major international firms regarding the obtaining of the market leadership in the Mexican audit due to its alternation between these large audit firms over our analyzed study period. Thus, we see that the firm Ernst \& Young for the year 2000 obtained the leadership with a market share of approximately $48 \%$, then in the following year it yielded top ranking to the former Arthur Andersen in 2002, which achieved to absorb approximately $40 \%$ of total market share. Similarly, we see in Table 3 that for the years from 2002 to 2006 the undisputed first place in our ranking was for PriceWaterhouseCoopers with $40 \%$ on average of the total market share. However, note that in the last year of our study period analyzed such audit firm seems to have lost competitiveness in the Mexican audit market, having significantly reduced its market share to the point that by 2007 
it has been forced to give leadership to the firm KPMG. Regarding KPMG and the results in Table 3, we highlight the steady rise in the Mexican audit market over the study period analyzed, achieving to jump from fifth place in 2000 to first place in our ranking in 2007, thereby occupying the absolute leadership in 2007 with a market share of approximately $36 \%$ achieved. Because the firm of Deloitte Touche Tohmatsu as the results in Table 3, we see a second place in our rankings for the years from 2003 to 2007. Also noted in Table 3, for Deloitte Touche Tohmatsu, the steady increase in market share during the study period analyzed between 2000 and 2007 inclusive, and we also highlight the $30 \%$ share market achieved in 2007. We also note that in 2002 the firm of Deloitte Touche Tohmatsu significantly increased its market share, after its merge with Arthur Andersen, from a 12\% market share in 2001 to $21 \%$ in 2002. In this regard we should also note the significant market share achieved by PriceWaterhouseCoopers in 2002 as a result of the absorption of a large part of the market share until 2001, previously controlled by firm Arthur Andersen, going from a $22 \%$ in 2001 to a $48 \%$ in 2002. This also allows us to infer the existence of a "rebalancing" in the distribution of Mexican audit market in the year 2002 after the market exit of Arthur Andersen because of its involvement in the Enron accounting scandal in the 2002.

Now the study of market concentration based on the absorption of activity by the major companies, has the limitation that it does not analyze jointly the companies operating in it. For this reason, studies of market concentration often use indices that take into consideration all firms in a given sample, and the Herfindahl Index one of the most used. The Herfindahl index allows us to take into account both the number of active firms and the variation in their activity levels. Therefore, if the index is equal to one, this result indicates that there is only one firm active in the market while if the result leans to zero, then we have a market with many coexisting similarly sized companies.

In this regard, some authors in specialized accounting literature argue that the choice between different measures of concentration is unlikely to affect inferences about the concentration in the audit market (Beattie Fearnley, 1994, Hogan and Jeter, 1999). However, other accounting researchers advocate the use of the Herfindahl index because it takes into account all active companies giving a better idea of the actual level of concentration (Minyard and Tabor, 1991). Therefore, below in Table 4 show the results reached Herfindahl as follows:

Table 4 . Herfindahl index by billing volume of audited companies

\begin{tabular}{lcccccccc}
\hline Herfindahl index & $\mathbf{2 0 0 0}$ & $\mathbf{2 0 0 1}$ & $\mathbf{2 0 0 2}$ & $\mathbf{2 0 0 3}$ & $\mathbf{2 0 0 4}$ & $\mathbf{2 0 0 5}$ & $\mathbf{2 0 0 6}$ & $\mathbf{2 0 0 7}$ \\
\hline $\begin{array}{l}\text { Billing Volume of audited } \\
\text { companies }\end{array}$ & $31 \%$ & $27 \%$ & $32 \%$ & $33 \%$ & $31 \%$ & $25 \%$ & $25 \%$ & $27 \%$ \\
\hline
\end{tabular}

From the results in Table 4, we show that the level of concentration in the audit Mexican market, considering the volume of sales is around $29 \%$ on average over the study period analyzed comprising the years from 2000 to 2007 . We also found that the level of concentration in the audit Mexican market for each year of the study period analyzed, ie for the period covering the years from 2000 to 2007 the results of calculating the Herfindahl index were $31 \%, 27 \%$, $32 \%, 33 \%, 31 \%, 25 \%, 25 \%$ and $27 \%$ respectively.

Now, based on the $27 \%$ obtained through the Herfindahl index in 2007, we can conclude that the concentration of the audit market in 2007 for Mexico is equivalent to a structure in which audit firms act a 3.7\% on average. We can also conclude that the audit Mexican market has gained some degree of competition among audit firms active, going from a $31 \%$ in 2000 to a $27 \%$ in 2007 respectively. Finally and from the results obtained from our empirical study, we can conclude that given the high level of audit market concentration in Mexico, the Mexican competitive nature of this market is for the most part determined by the behavior of the Big Four firms international auditing, best known as the Big 4.

\section{Conclusions}

The research work that we present in this article is an important Mexican contribution to the group of studies that have been made at an international level on the structure and operation of the world financial audit markets, and in our particular case, this research refers to the study of the structure and nature of the competition in the market for financial audit services in Mexico during the period from 2000 to year 2007. Upon completion of the work, we have reached the following conclusions:

FIRST: The first approximation we have made to the way the market operates audit services in Mexico has been through the paradigm-behaviors-performance structure. The findings indicate that this is a suitable, well-adapted structuralist paradigm for conducting research in the Mexican audit market. 
SECOND: The analysis of the international literature allows observing that the high level of structure concentrated power of big international firms known as the Big 4 is present in all countries regardless of whether countries are dealt with more or less tradition in auditing the financial statements of companies.

THIRD: Given the results of our empirical study on the structure and nature of the competition of the audit market in Mexico from 2000 to 2007, we can conclude that the market is highly concentrated and dominated by only four audit firms, which are the four major international firms. These results agree with those obtained in other countries, which also involved the Big 4.

With the exposure of these findings we completed our research, which was conducted with the desire to provide evidence to better understand the current operation of market forces in Mexico audit that define the actions of auditors and firms audited. Not before, reflect on the following questions that will serve for further research:

$>$ Does the merger of large auditing firms not a viable option to increase competition in the audit market?

$>$ Are tax incentives and taxes a viable option for governments and regulators can implement to incentivize large audit firms do not merge with each other?

$>$ Is the compulsory division of the Big 4 a viable option to increase competition in the audit market?

\section{References}

Abidin, S., Beattie, V., \& Goodacre, A. (2010). Audit market structure, fees and choice in a period of structural change, British Accounting Review, 2(3), 187-206. http://dx.doi.org/10.1016/j.bar.2010.04.002

American Assembly Report (2005). The Future of the Accounting Profession: Auditor Concentration. May 23, 2005. New York, NY USA.

Baskerville, R. \& Hay D. (2006): "The Effect of Accounting Firm Mergers on the Market for Auditory Services: New Zealand Evidence". Abacus, Vol. 42. (1) pp. 87-104. http://dx.doi.org/10.1111/j.1467-6281.2006.00186.x

Beattie, V. \& Fearnley, S. (1994). The Changing Structure of the Market for Audit Services in the UK-A Descriptive Study, British Accounting Review, Vol. 26, December, pp. 301-322. http://dx.doi.org/10.1006/bare.1994.1021

Beattie, V.; Goodacre, A. \& Fearnley, S. (2003). "And then there were four: A study of UK audit market concentration - causes, consequences and the scope for market adjustment", Journal of Financial Regulation and Compliance, Vol. 11 (3) pp. 250-265. http://dx.doi.org/10.1108/13581980310810561

Bigus, J., \& Zimmermann, R. C. (2008). Non audit fees, market leaders and concentration in the German audit market. International Journal of Auditing, 12(3), 159-179. http://dx.doi.org/10.1111/j.1099-1123.2008.00378.x

Breitkreuz, R., \& Mue ig, A. (2010). Kritische Analyse der Anbieterkonzentration aud dem Schweizer Markt für Revisions- und Beratungsleistungen. Kapitalmarktorientierte und international Rechnungslegung, 11 (10), pp. 510-514.

Bueno, E. \& Morcillo, P. (1993). Fundamentos de economía y organización Industrial, McGraw-Hill, Madrid, España.

Caban-García, M. T., \& Cammack, S. E. (2009). Audit Firm Concentration and Competition. Journal of Theoretical Accounting Research, 25 (5), pp. 1-24.

Carlton, D. \& Perloff, J. (1999). Modern Industrial Organization, Wesley Longman, Inc., California, USA.

Carrera, N. M.; Gutierrez, I. \& Carmona, S. (2005). Concentración en el Mercado de Auditoría en España: Análisis Empírico del Período 1990-2000, Revista Española de Financiación y Contabilidad, V. XXXIV, (125), p. 423-457. http://dx.doi.org/10.1080/02102412.2005.10779552

Competition Commission (2013). Statutory Audit Services Market Investigation. Online http://www.competition-commissino.org.uk/assets/competitioncommission/docs/2011/statutory-audit-services/p rovisional_findings_report.pdf

Danos, P. \& Eichenseher, J. (1986). Long-Term Trends Toward Seller Concentration in the U. S. Audit Market, The Accounting Review, Vol. 61, No. 4, pp. 633-650.

Dopuch, N. \& Simunic, D. (1980). The Nature of Competition in the Auditing Profession: A Descriptive and Normative View, Regulation and the Accounting Profession, Buckley, J. W. y Weston, J. F. Lifetime Learning Publications, pp. 77-94. 
Dunn, K., Kohlbeck, M., \& Mayhew, B. W. (2011). The Impact of the Big 4 Consolidation on Audit Market Share Equality. Auditing, 30(1), 49-73. http://dx.doi.org/10.2308/aud.2011.30.1.49

Eichenseher, J. \& Danos, P. (1981). The Analysis of Industry-Specific Auditor Concentration: Towards an Explanatory Model, The Accounting Review, Vol. 56, No. 3, pp. 479-492.

European Commission (2010). Green Paper: Audit Policy: Lessons from the Crisis. $<$ http://ec.europa.eu/internal_market/consultations/docs/2010/audit/green_paper_audit_en>. Brussels European

Feldman, E. R. (2006). A basic quantification of the competitive implications of the demise of Arthur Andersen, Review of Industrial Organization, 29 (3), pp. 193-212. http://dx.doi.org/10.1007/s11151-006-9117-5

García-Benau, M. A., Ruíz B. E., \& Vico, M. A. (1998). Análisis de la estructura del mercado de servicios de auditoría en España. VI Premio de investigación Contable "José María Fernández Pirla". ICAC, Ministerio Economía y Hacienda, Madrid.

García-Benau, M.A. \& Novejarque, C. J. (2009). Europa quiere potenciar la competencia en el mercado de auditoría. Partida Doble, núm. 207, pp. 82-90, February, 2009.

General Accounting Office (2003). Public Accounting Firms: Mandated Study on Consolidation and Competition, (General Accounting Office) retrieved July 3rd, 2003, from http://www.gao.gov.

Grothe, J. (2005). Branchenspezialisierungen von Wirtschaftspruefungsgesellschaften im Rahmen der Jahresabschlusspruefung. Duesseldorf: IDW.

Hogan, C. E., \& Jeter, D. C. (1999). Industry Specialization by Auditors, Auditing: A Journal of Practice \& Theory, Vol. 18, No. 1, pp. 1-17. http://dx.doi.org/10.2308/aud.1999.18.1.1

Iyer, V., \& Iyer, G. (1996). Effect of Big 8 Mergers on Audit Fees: Evidence from the United Kingdom, Auditing: A Journal of Practice \& Theory, Vol. 15, No. 2, pp. 123-132.

Johnson, E., Walker, K., \& Westergaard, E. (1995). Supplier Concentration and Pricing of Audit Services in New Zealand, Auditing: A Journal of Practice \& Theory, No. 2, pp. 74-89.

Kallapur, S., Sankaraguruswamy, S., \& Zang, Y. (2010). Audit Market Concentration and Audit Quality.

Kwon, S. Y. (1996). The Impact of Competition within the Client's Industry on the Auditor Selection Decision, Auditing: A Journal of Practice \& Theory, Vol. 15, No. 1, pp. 53-70.

Maijoor, S., Buijink, W., Witteloostuijn, A., \& Zinken, M. (1995). Long-Term Concentration in the Dutch Audit Market: The Use of Auditor Association Membership List in Historical Research, Abacus, Vol. 31, No. 2, pp. 152-177. http://dx.doi.org/10.1111/j.1467-6281.1995.tb00360.x

McMeeking, K. P., Peasnell, K. V., \& Pope, P. F. (2007). The effect of large audit firm mergers on audit pricing in the UK. Accounting and Business Research, 37(4), 301-319. http://dx.doi.org/10.1080/00014788.2007.9663314

McMeeking, K.P. (2007). Competition in the UK accounting services market, Managerial Auditing Journal, 22(2), pp. 197-217. http://dx.doi.org/10.1108/02686900710718681

Minyard, D. H., \& Tabor, R. H. (1991). The Effect of Big Eight Mergers on Auditor Concentration, Accounting Horizons, Vol. 5, pp. 79-90.

Moizer, P., \& Turley, S. (1987). Surrogates for audit fees in concentration Studies, Auditing: A Journal of Practice \& Theory, Vol. 7 No. 1, pp. 118-123.

Moizer, P., \& Turley, S. (1989). Changes in the UK Market for Audit Services: 1972-1982, Journal of Business Finance and Accounting, Vol. 16, pp. 41-53. http://dx.doi.org/10.1111/j.1468-5957.1989.tb00003.x

Oxera Report (2006). Competition and choice in the UK audit market, Prepared for Britain's accounting regulator, (FRC) and the Department of Trade and Industry, pp. 01-152.

Pong, C. K. P. (1999). Auditor Concentration: A Replication and Extension for the UK Audit Market (1991-1995), Journal of Business Finance and Accounting, Vol. 26, No. 3-4, pp. 451-475. http://dx.doi.org/10.1111/1468-5957.00263

Porter, M.E. (1985). Competitive Advantage: Creating and sustaining superior performance. New York USA: Free Press. 
Quick, R., \& Sattler, M. (2011). Das Erfordernis der Umsatzunabhaengigkeit und die Konzentration auf dem deutschen Markt fuer Abschlussprueferleistungen. Zeitschrift fuer Betriebswirtschaft, 81 (1), 61-98. http://dx.doi.org/10.1007/s11573-010-0425-8

Quick, R., \& Wolz, M. (1999). Concentration on the German Audit Market-An Empirical Analysis of the Concentration on the German Market for Stock Corporation Audits, International Journal of Auditing, Vol. 3, pp. 175-189. http://dx.doi.org/10.1111/1099-1123.00058

Rhode, J., Whitsell, G., \& Kelsey, R. (1974). An Analysis of Client Industry Concentrations for Large Public Accounting Firms, The Accounting Review, Vol. 49, No. 4, pp. 772-786.

Sarbanex-Oxley Act (2002). Corporate Responsibility Public Law, 107th Congress of the United States, pp. 107-204.

Schaen, M., \& Maijoor, S. (1997). The Structure of the Belgian Audit Market: the Effects of Clients' Concentration and Capital Market Activity, International Journal of Auditing 1(2), pp. 151-162. http://dx.doi.org/10.1111/1099-1123.00019

Scherer, F., \& Ross, D. (1990). Industrial Market Structure and Economic Performance, Boston, Houghton Mifflin Co, 3rd Ed, 4.

Thavapalan, S., Moroney, R., \& Simnett, R. (2002): The Effect of the PricewaterhouseCoopers Merger on Auditor Concentration in Australia: A Note. Accounting and Finance, Vol. 42, pp. 153-167. http://dx.doi.org/10.1111/1467-629X.00014

Tomczyk, S., \& Read, W. J. (1989). Direct Measurement of Supplier Concentration in the Market for Audit Services, Auditing: A Journal of Practice \& Theory, Vol. 9, No. 1, pp. 98-106.

Tonge, S. D., \& Wootton, C. W. (1991). Auditor Concentration and competition Among the Large Public Accounting Firms: Post-Merger Status and Future Implications, Journal of Accounting and Public Policy, Vol. 10, pp. 157-172. http://dx.doi.org/10.1016/0278-4254(91)90010-H

Wolk, C. M., Michelson, S. E., \& Wootton, CH. W. (2001), Auditor Concentration and Market Shares in the US: 1988-1999 A Descriptive Note, British Accounting Review, 33, pp. 157-174. http://dx.doi.org/10.1006/bare.2001.0159

Working Paper, Gachibowli. http://dx.doi.org/10.1596/1813-9450-5493

Zeff, S., \& Fossum, R. (1967). An analysis of Large Audit Clients, The Accounting Review, Vol. 42, No. 2. April, pp. 298-320. 